\title{
Characterization of the Deltaproteobacteria in contaminated and uncontaminated stream sediments and identification of potential mercury methylators
}

\author{
Jennifer J. Mosher ${ }^{1,3}$, Tatiana A. Vishnivetskaya ${ }^{1,4}{ }^{,}$Dwayne A. Elias ${ }^{1}$, Mircea Podar ${ }^{1}$, \\ Scott C. Brooks ${ }^{2}$, Steven D. Brown ${ }^{1}$, Craig C. Brandt ${ }^{1}$, Anthony V. Palumbo ${ }^{1, *}$ \\ ${ }^{1}$ Biosciences Division, and ${ }^{2}$ Environmental Sciences Division, Oak Ridge National Laboratory, Oak Ridge, Tennessee 37831, USA \\ ${ }^{3}$ Present address: Stroud Water Research Center, Avondale, Pennsylvania 19311, USA \\ ${ }^{4}$ Present address: Center for Environmental Biotechnology, University of Tennessee, Knoxville, Tennessee 37998, USA
}

\begin{abstract}
Microbial communities were examined in surface stream sediments at 5 contaminated sites and 1 control site near Oak Ridge, TN, USA, to identify bacteria that could be contributing to mercury $(\mathrm{Hg})$ methylation. The phylogenetic composition of the sediment bacterial community was examined over 3 quarterly sampling periods (36 samples) using 16S rRNA gene pyrosequencing. Only 3064 sequences $(0.85 \%$ of the total community) were identified as Deltaproteobacteria, the only group known to methylate $\mathrm{Hg}$, using the Ribosomal Database Project classifier at the $99 \%$ confidence threshold. Constrained ordination techniques indicated statistically significant positive linear correlations between Desulfobulbus spp., Desulfonema spp. and Desulfobacca spp. and methyl-Hg concentrations at the Hg-contaminated sites. In contrast, the distribution of organisms related to Byssovorax spp. was significantly correlated to inorganic carbon, nitrate and uranium concentrations but not to Hg or methyl-Hg. Overall, the abundance and richness of Deltaproteobacteria sequences were higher in uncontaminated sediments, while the majority of the members present at the contaminated sites were either known potential metalreducers/methylators or metal tolerant species. Given the abundance relative to other known $\mathrm{Hg}$ methylators and the association with methyl-Hg, Desulfobulbus spp. is considered a prime candidate for involvement in Hg methylation in these streams.
\end{abstract}

KEY WORDS: Deltaproteobacteria $\cdot$ Mercury $\cdot$ Methylmercury $\cdot$ Stream sediments

\section{INTRODUCTION}

Mercury (Hg) contamination is a concern at several U.S. Department of Energy sites, including a stream that flows through the city of Oak Ridge, TN, where high levels of both inorganic and methyl Hg have been found (Barnett et al. 1995, Han et al. 2006, Oregaard \& Sorensen 2007). Hg methylation is an important biogeochemical process that generates the potent human neurotoxin monomethylmercury
(MeHg) (Clarkson 1998). Net MeHg production in aquatic ecosystems is linked to environmental and geochemical parameters along with electron donor and acceptor availability (Marvin-DiPasquale et al. 2009). Previously, wetlands and floodplain lakes have been associated with $\mathrm{MeHg}$ production in aquatic ecosystems, but recent work in stream sediments has found significant in situ MeHg production that warrants further examination of streambed $\mathrm{Hg}$ methylation and the associated microbial communi- 
ties (Tsui et al. 2010). Most of the previous work in streams has been performed in anoxic, subsurface sediments and porewater, but $\mathrm{MeHg}$ can be produced in surface sediments within the anaerobic microniches in sedimentary biofilms (Bloom et al. 1999). A study of stream water and surface sediments in an Hg mining impacted watershed showed significant downstream transport of $\mathrm{Hg}$ from the point source and subsequent in situ methylation (Gray et al. 2004).

Hg methylation has been linked primarily to Deltaproteobacteria, including sulfate-reducing bacteria (Gilmour et al. 1992, Devereux et al. 1996, King et al. 2000, Ranchou-Peyruse et al. 2009) and more recently iron-reducing bacteria (Fleming et al. 2006, Kerin et al. 2006). Whether or not microorganisms outside the Deltaproteobacteria are able to methylate $\mathrm{Hg}$ remains an open question. A study in streambed sediments and surrounding watershed soils found Desulfovibrio spp. and Desulfobacter spp. associated with $\mathrm{Hg}$ methylation (Holloway et al. 2009). While these bacteria are primarily anaerobic, there are sulfate-reducing members of the class Deltaproteobacteria that will survive and grow under oxic conditions (Krekeler et al. 1997, Sigalevich \& Cohen 2000, Sigalevich et al. 2000a). Although the aerobic metabolism of these organisms involves oxidation of sulfide and sulfite, when conditions become void of oxygen, anaerobic respiration commences, including sulfatereduction (Sigalevich et al. 2000b), which may facilitate Hg methylation in surface sediments (Achá et al. 2005).

Close examination of microbial communities in environmental samples is difficult due to a lack of resolution (e.g. fingerprinting techniques) or low detection limits (FISH) (Ravenschlag et al. 2000, Wang \& He 2011). The present study utilized highthroughput sequencing targeted to the $16 \mathrm{~S}$ rRNA gene because it is a powerful tool for microbial ecology. Recent advances, such as the bacterial tag encoded FLX pyrosequencing method, have enabled this technique to be applied to the analysis of numerous diverse environmental samples. The 'bar-tagging' approach uses sample specific sequence tags incorporated in the amplification primers (Dowd et al. 2008, Youssef et al. 2009).

Recent studies have investigated the overall bacterial and archaeal community structures in streams of East Tennessee contaminated with mercury and other heavy metals (Porat et al. 2010, Vishnivetskaya et al. 2011). The goal of the present study was to further these efforts and concentrate on the known guild of methylating bacteria by characterizing the distribution of Deltaproteobacteria in the anthropogenically contaminated surface sediments of streams within the Oak Ridge Reservation. More specifically, these efforts were focused on (1) establishing relationships between the distribution of deltaproteobacterial members and chemical variables measured in the streams and (2) determining if the Deltaproteobacteria present could be identified as close relatives of known $\mathrm{Hg}$ methylators and thus as candidates for methylating mercury in these streams.

\section{MATERIALS AND METHODS}

Stream sediment samples were obtained from 6 sampling sites of 4 streams located in or near the Department of Energy reservation in Oak Ridge, TN. Locations included 5 contaminated sites: 3 sites in East Fork Poplar Creek (EFK [K = river kilometer measured from the mouth of the creek] 6.3, EFK 13.8, and EFK 23.4), 1 site in Bear Creek (BCK 12.3), and 1 site in White Oak Creek (WCK 3.9). Hinds Creek (HCK 20.6) was used as an uncontaminated reference site with similar general chemistry, hydrology and underlying geology to the contaminated sites (Fig. 1).

Samples were collected in May, July and September of 2008. Two samples were collected at each site, one from the middle of the stream and a second adjacent to the stream bank (herein referred to as midchannel and bank samples), by skimming the upper 2 to $3 \mathrm{~cm}$ of sediment with a sterile wide-mouthed high-density polyethylene (HDPE) jar and immediately transferring the material to a sterile HDPE 11 bottle. Water samples were collected at the same locations as the sediment samples for laboratory analysis of dissolved metals and anions, dissolved inorganic and organic carbon (DIC and DOC), soluble reactive phosphorous, dissolved $\mathrm{Hg}$, total $\mathrm{Hg}$ in sediment and dissolved MeHg. For detailed methods, see Vishnivetskaya et al. (2011).

All sediment and water samples were placed immediately on ice and returned to the laboratory within $2 \mathrm{~h}$. Immediately upon arrival at the laboratory, sediment samples were centrifuged $\left(3700 \times g_{1}\right.$ $4^{\circ} \mathrm{C}$, 30 min; Sorvall Legend RT Benchtop Centrifuge, Thermo Fisher Scientific). Gravel and pebbles were removed, while fine sediments $(<2 \mathrm{~mm}$ grain size) were frozen $\left(-80^{\circ} \mathrm{C}\right)$ until analysis and DNA extraction. A total of 36 surface sediment samples were collected and analyzed. 


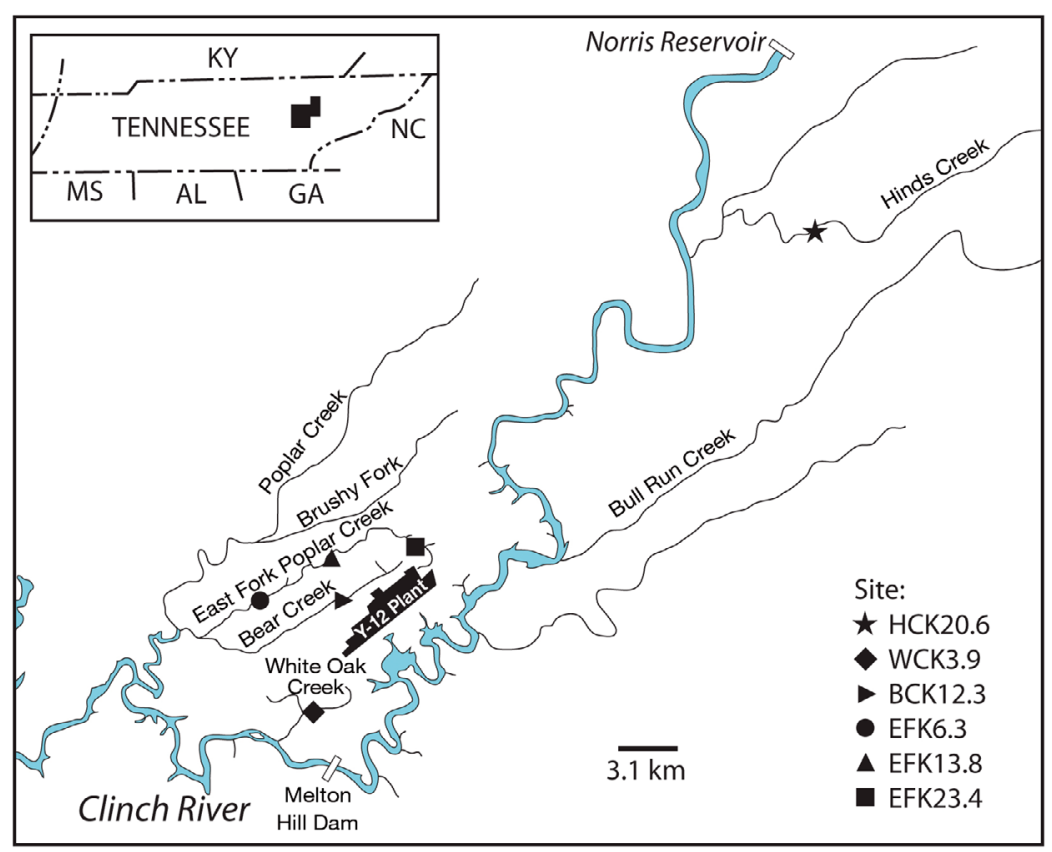

Fig. 1. Sampling sites used in the present study. The background site (HCK20.6) is located $\sim 23 \mathrm{~km}$ linear distance upstream from site EFK23.4. The industrial facility (Y-12 Plant) is indicated schematically

\section{Environmental DNA extraction and pyrosequencing of the bacterial 16S rRNA genes}

The total community genomic DNA (cgDNA) was extracted from $\sim 1 \mathrm{~g}$ (wet weight) of sediment using a PowerSoil ${ }^{\mathrm{TM}}$ DNA Isolation kit (MO BIO Laboratories) and quantified using a NanoDrop 1000 spectrophotometer (Thermo Scientific). Pyrosequencing of the cgDNA isolated from 36 samples was conducted using the method described at the Ribosomal Database Project (RDP) Pyrosequencing Pipeline (http://pyro.cme.msu.edu/index.jsp). Briefly, the hypervariable V4 region ( $290 \mathrm{bp}$ ) of the $16 \mathrm{~S}$ rRNA gene was amplified using a primer set identical to that described in the RDP Pyrosequencing Pipeline; primers contained sequences (adaptors) required for GS 454 FLX pyrosequencing, and the forward primer contained an additional short key (tag) sequence, so that 40 samples could be analyzed in 1 sequencing run. PCR reactions $(50 \mu \mathrm{l})$ consisted of $1.5 \mu \mathrm{l}$ of each forward and reverse primer (10 $\mu \mathrm{M}$ each), $1 \mu$ template

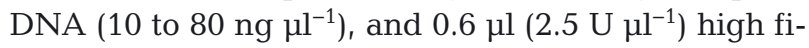
delity AccuPrime ${ }^{\mathrm{TM}}$ PfX DNA polymerase (Invitrogen). Samples were initially denaturated at $95^{\circ} \mathrm{C}$ for $2 \mathrm{~min}$, then amplified using 30 cycles of $95^{\circ} \mathrm{C}$ for $15 \mathrm{~s}, 55^{\circ} \mathrm{C}$ for $30 \mathrm{~s}$ and $68^{\circ} \mathrm{C}$ for $45 \mathrm{~s}$, with a final extension of $3 \mathrm{~min}$ at $68^{\circ} \mathrm{C}$. Template controls were always included. The PCR amplicons were purified using the
Agencourt AMPure solid-phase paramagnetic bead technology (Agencourt Bioscience). The purity, concentration and size of the PCR amplicons were estimated using DNA 1000 chips and an Agilent 2100 Bioanalyzer (Agilent Technologies). Sequencing reactions were performed on a GS 454 Life Sciences Genome Sequencer FLX (Roche Diagnostics). Raw 454 FLX data $(\sim 235670 \mathrm{Mb})$ were initially processed through the RDP pyrosequencing pipeline (Cole et al. 2009). During this process, sequences were sorted by tag sequence, and the $16 \mathrm{~S}$ primers and low-quality sequences were removed. From 5580 to 16706 high quality sequences of 200 to 220 bp were obtained for each sample.

\section{Phylogenetic analyses}

Bacterial 16S rRNA sequences were assigned to a set of hierarchical taxa using a naïve Bayesian rRNA classifier version 2.0 with a confidence threshold of $99 \%$ (http://rdp.cme. msu.edu/classifier/classifier.jsp) (Wang et al. 2007). Sequences from the present study were subsequently aligned using the fast, secondary-structure aware Infernal aligner (Nawrocki \& Eddy 2007) and clustered by the complete-linkage clustering method available through the RDP Pyrosequencing Pipeline.

\section{Statistical analyses}

Constrained ordination techniques were used to identify patterns of variation of the Deltaproteobacteria sequences among streams and correlations between the distribution of the sequences and environmental descriptors. Sequence abundances for each genera were converted into weight percentage values by dividing by the total abundance for that sample; weight percentage values were natural log transformed $(\mathrm{ln}+1)$. Detrended correspondence analysis (DCA), an indirect gradient analysis based on segment length, was performed to determine the modality of the sequence data. The analyses resulted in short $(<2.0)$ segment lengths, indicating that the datasets were linear; thus, redundancy analysis (RDA) was performed (CANOCO 4.5, Microcomputer Power). RDA identified patterns of variation and cor- 
related those patterns to all environmental descriptors in the 36 samples (see Tables S1 to S3 in the supplement at www.int-res.com/articles/suppl/a066p271_ supp.pdf), when complete geochemical measurements were available. Sequence data were used as the response variables, and the predictor variables used were the measured environmental and geochemical parameters. All physical parameters were entered into the analysis, but forward selection of the predictor variables followed by Monte Carlo permutation tests was used to prevent artificial inflation of variation due to autocorrelation in the constrained ordination model (Leps \& Smilauer 2003).

\section{Cluster analysis}

Phylogenetic analysis was also utilized to compare the sequences detected in the samples from the present study to known methylators found in previous studies to identify potential Hg methylators in the sediments. All Deltaproteobacteria sequences were clustered at $97 \%$ through the RDP pyrosequencing pipeline, and representative sequences from the clusters containing $>10$ sequences were selected and aligned with sequences of 33 known Deltaproteobacteria including methylators and non-methylators (King et al. 2000, Jay et al. 2002, Ekstrom et al. 2003, Fleming et al. 2006, Kerin et al. 2006, Ekstrom \& Morel 2008, Schaefer \& Morel 2009). A phylogenetic tree using the neighbor-joining method (Saitou \& Nei 1987) was constructed with the combined dataset to examine relationships between the 13 representative environmental sequences from the present study to 33 culturable strains of Deltaproteobacteria using MEGA4 software (Tamura et al. 2007). Evolutionary distances were computed using the maximum composite likelihood method (Tamura et al. 2004) and bootstrap values based on 100 replicates (Felsenstein 1985).

\section{Nucleotide sequence accession number}

The 16S rRNA gene pyrosequences identified as Deltaproteobacteria at the $99 \%$ confidence level from the RDP database were deposited in GenBank under accession numbers GQ458262 to GQ461334.

\section{RESULTS}

\section{Stream geochemistry characteristics}

The ranges of mercury concentrations and selected chemical and physical parameters for the 6 sampling sites are summarized in Table 1. The complete dataset for dissolved metals and anions, DIC, soluble reactive phosphorous, dissolved $\mathrm{Hg}$ and $\mathrm{MeHg}$ and total sediment $\mathrm{Hg}$ was recently published (Vishnivetskaya et al. 2011) and is presented herein (see Table S1A-C in the supplement).

\section{Microbial community description}

The Deltaproteobacteria made up a small portion of the 359307 high quality sequences of 200 to $250 \mathrm{bp}$ that remained after processing the 36 samples (Table 2). The sequence data were taxonomically assigned using the RDP Classifier (Wang et al. 2007) at the $99 \%$ confidence level. The $99 \%$ confidence level was chosen to allow some room for sequence errors but to yield high assurance that the sequences used in the analysis were truly associated with Deltaproteobacteria. The Deltaproteobacteria constituted 0.9 to $2.7 \%$ of the total bacterial sequences in each sample (Table 2). The site with the highest concentrations of nitrate, uranium and other metals (BCK 12.3) was equivalent to other sites in the number of Deltaproteobacteria sequences as other stations over-

Table 1. Mean stream water and sedimentary concentrations of selected ions from the 6 study sites. A full list of geochemical parameters is located in the supplement at www.int-res.com/articles/suppl/a066p271_supp.pdf. Hg sediment samples were extracted from sediment samples; the rest of the ions were from stream water samples. Data are the averages of duplicate samples taken over 3 sampling dates (May, July and September). Numbers in parentheses are the standard error. RK: river kilometer

\begin{tabular}{|lcccccc|}
\hline & $\begin{array}{c}\text { Hg sediment } \\
\left(\mathrm{ng} \mathrm{mg}^{-1}\right)\end{array}$ & $\begin{array}{c}\text { Hg dissolved } \\
\left(\mathrm{ng} \mathrm{l}^{-1}\right)\end{array}$ & $\begin{array}{c}\text { MeHg } \\
\left(\mathrm{ng} \mathrm{l}^{-1}\right)\end{array}$ & $\begin{array}{c}\text { Uranium } \\
\left(\mu \mathrm{l}^{-1}\right)\end{array}$ & $\begin{array}{c}\text { Nitrate } \\
\left(\mathrm{mg} \mathrm{l}^{-1}\right)\end{array}$ & $\begin{array}{c}\text { Manganese } \\
\left(\mu \mathrm{l}^{-1}\right)\end{array}$ \\
\hline HCK 20.6 & $0.06(0.02)$ & $1.50(0.31)$ & $0.03(0.03)$ & $2.49(1.55)$ & $0.09(0.03)$ & $43.30(35.30)$ \\
EFK 6.3 & $13.50(2.59)$ & $22.30(7.28)$ & $1.21(0.53)$ & $6.90(1.64)$ & $0.64(0.08)$ & $1580.00(1070.00)$ \\
EFK 13.8 & $14.90(1.29)$ & $42.00(17.20)$ & $0.30(0.03)$ & $6.70(0.33)$ & $0.18(0.06)$ & $62.30(4.78)$ \\
EFK 23.4 & $39.30(5.04)$ & $81.10(16.50)$ & $0.52(0.12)$ & $7.36(0.22)$ & $0.27(0.05)$ & $30.40(3.74)$ \\
BCK 12.3 & $1.61(0.06)$ & $4.87(0.32)$ & $0.05(0.03)$ & $224.00(28.90)$ & $15.40(1.05)$ & $8.75(4.78)$ \\
WCK 3.9 & $8.37(3.52)$ & $5.25(3.52)$ & $0.34(0.25)$ & $0.37(0.06)$ & $0.15(0.09)$ & $20.90(5.92)$ \\
\hline
\end{tabular}


all (Table 2) but was virtually devoid of sequences corresponding to sulfate-reducing bacteria, with up to 4 sequences found at some sampling times and none at others.

The Deltaproteobacteria community was represented by sequences from 25 genera within 14 families and 7 orders (Fig. 2). The lowest genetic richness was found at the site with the highest concentration of nitrate and uranium (BCK 12.3), with only 11 of the 25 detected genera present; EFK 13.8 had the highest richness, with 21 genera present. Whether nitrate and uranium were driving factors in the community richness is unknown because several other factors may also contribute, such as higher $\mathrm{Ba}$ and $\mathrm{Sr}$ or lower $\mathrm{Al}$ or $\mathrm{Mn}$ levels at $\mathrm{BCK}$ 12.3. The reference stream, HCK 20.6, had 19 genera in the samples, and EFK 6.3, EFK 23.4 and WCK 3.9 each contained 17 genera.

The BCK 12.3 samples were the most distinct in Deltaproteobacteria community composition. The majority of the sequences in all samples grouped as unclassified Deltaproteobacteria (16.9-49.8\%), with

Table 2. Distribution and mean number of sequences extracted from stream sediments from 6 sites over 3 sampling dates. Standard deviation (in parentheses) represents the variation between the midchannel and near bank sampling sites

\begin{tabular}{|c|c|c|c|}
\hline \multirow{3}{*}{ HCK 20.6} & \multirow{2}{*}{$\begin{array}{c}\text { Bacterial } \\
\text { sequences }\end{array}$} & \multicolumn{2}{|c|}{ Deltaproteobacteria } \\
\hline & & sequences & $\%$ \\
\hline & & & \\
\hline May & 7189 (1294.0) & 71 (14.1) & $1.0(0.4)$ \\
\hline Jul & 9937 (3607.7) & $171(4.2)$ & $1.8(0.6)$ \\
\hline Sep & $15292(1974.2)$ & $226.5(17.7)$ & $1.5(0.1)$ \\
\hline \multicolumn{4}{|c|}{ EFK 6.3} \\
\hline May & $12985.5(157.7)$ & $129.5(20.5)$ & $1.0(0.2)$ \\
\hline Jul & $9415.5(3310)$ & $159(14.1)$ & $1.8(0.5)$ \\
\hline Sep & 7722.5 (2305.9) & $130(39.6)$ & $1.7(0.0)$ \\
\hline \multicolumn{4}{|c|}{ EFK 13.8} \\
\hline May & 10012.5 (3479.7) & 136 (43.8) & $1.4(0.0)$ \\
\hline Jul & 7817 (2076.8) & $196.5(33.2)$ & $2.7(1.1)$ \\
\hline Sep & $13280.5(40.3)$ & $278(8.5)$ & $2.1(.1)$ \\
\hline \multicolumn{4}{|c|}{ EFK 23.4} \\
\hline May & $9874(1506.1)$ & $114(17.0)$ & $1.2(0.3)$ \\
\hline Jul & $7170(2274.1)$ & $70(28.3)$ & $1.0(0.1)$ \\
\hline Sep & $11464(2180.7)$ & $119.5(57.3)$ & $1.0(0.3)$ \\
\hline \multicolumn{4}{|c|}{ BCK 12.3} \\
\hline May & 9680.5 (1638.4) & $105(25.5)$ & $1.1(0.4)$ \\
\hline $\mathrm{Jul}^{2}$ & 9992.5 (1782.6) & $94(38.2)$ & $0.9(0.2)$ \\
\hline Sep & 8389.5 (1448.9) & $87(32.5)$ & $1.0(0.2)$ \\
\hline \multicolumn{4}{|c|}{ WCK 3.9} \\
\hline May & 10772.5 (2192.7) & $133(17.0)$ & $1.2(0.1)$ \\
\hline Jul & 8994.5 (2445.9) & $95(35.4)$ & $1.0(0.1)$ \\
\hline Sep & $9355(77.8)$ & $137.5(10.6)$ & $1.5(0.1)$ \\
\hline
\end{tabular}

BCK 12.3 having the majority of unclassified Deltaproteobacteria sequences (33.3-49.8\%). Five genera were found in all samples: Geobacter (0.8-16.03\%), Byssovorax (0.97-11.1\%), Bdellovibrio (0.62-7.2\%), Anaeromyxobacter (0.8-5.7\%) and Bacteriovorax $(0.3-6.2 \%)$. Two of the aforementioned genera, Byssovorax (8.8-11.12\%) and Bdellovibrio (4.0-4.4\%), were found in highest abundance in the samples taken from BCK 12.3. Geobacter spp. were found in highest abundance in the uncontaminated site HCK 20.6 (5.6-16.03\%), while Anaeromyxobacter appeared to be evenly distributed across sites and sampling dates. Desulfobulbus (2.6-26.7\%) and Desulfonema (1.5-9.6\%) were found in all samples, with the exception of BCK 12.3, where no sequences were detected on any of the sampling dates. Of the 5 sampling sites where these 2 genera were present, there were no significant differences in the number of sequences detected amongst the samples for Desulfobulbus spp. ( $\mathrm{p}=0.475, F=0.905)$. Conversely, Desulfonema spp. sequences were found in significantly lower abundances at EFK 23.4 than at the other sites where it was found ( $\mathrm{p}=0.043, F=2.87$ ).

\section{Microbial community composition in relation to geochemical parameters}

The microbial community composition was analyzed using all 36 samples (from the 3 sampling dates) (see Fig. S1 in the supplement at www.intres.com/articles/suppl/a066p271_supp.pdf), and because $\mathrm{MeHg}$ data were only available from the May and July 2008 sampling dates, an RDA analysis was performed including only the 24-sample subset to determine if $\mathrm{MeHg}$ concentrations in the sediments were associated with microbial community composition (Fig. 3A). The RDA triplot of the subset of samples that included $\mathrm{MeHg}$ data described $40.7 \%$ of the variation ( $\mathrm{p}=0.002, F=6.39$ ). The majority of the variation (36.2\%) was described by RDA Axis 1, and the BCK 12.3 samples grouped away from the other samples with good replication for each sampling date. Because many of the geochemical parameters measured in the present study were autocorrelated, isolation of the individual influences from each geochemical parameter was not always possible. Forward selection of the independent variables followed by Monte Carlo permutations during the RDA selected the most significant $(p<0.05)$ environmental variable. The BCK 12.3 samples had higher abundances of Byssovorax and unclassified members of Deltaproteobacteria and significant correlation with 


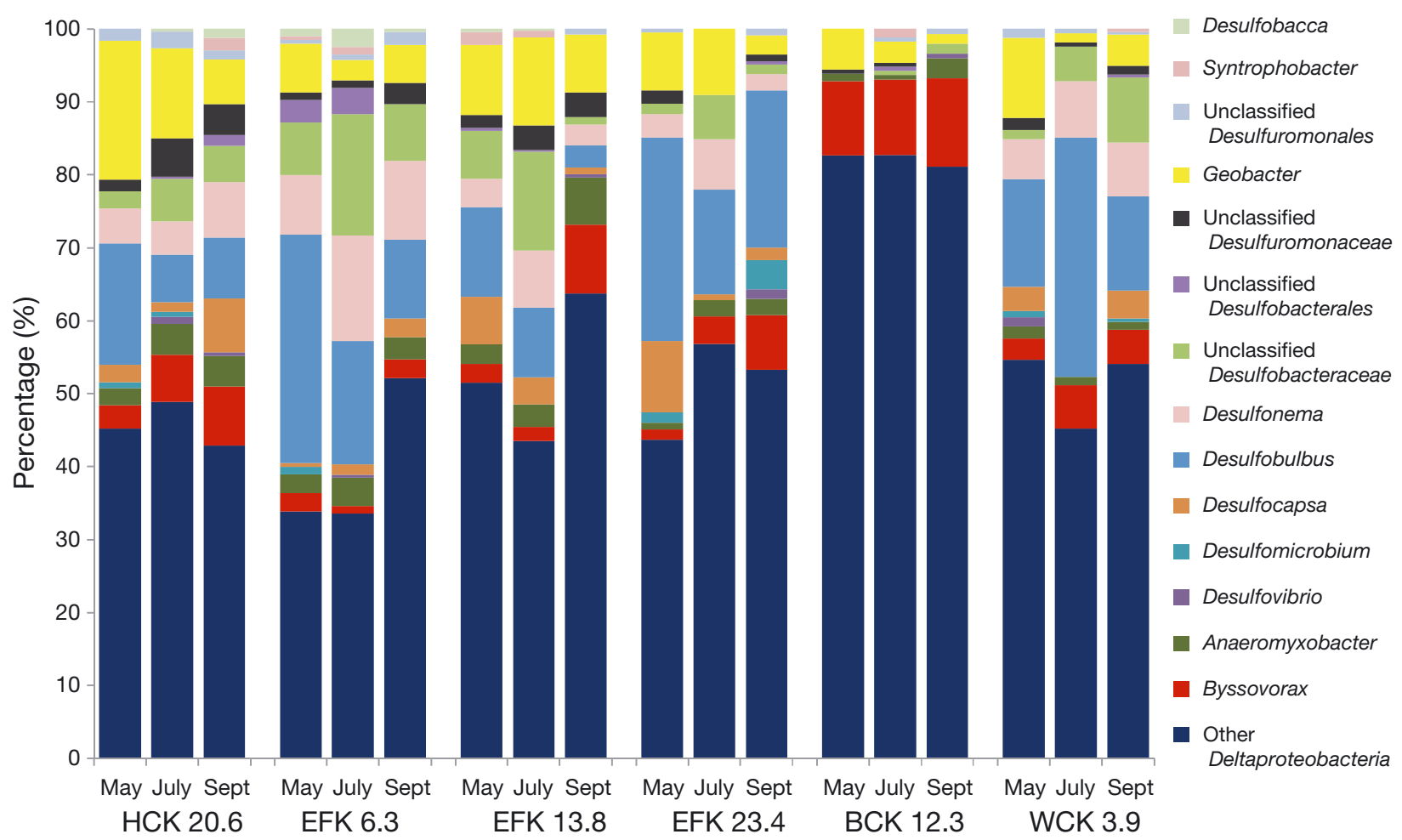

Fig. 2. Percent contribution of identified members of Deltaproteobacteria extracted from stream sediments from 6 sites over 3 sampling dates

uranium concentrations ( $R=0.7671)$ as well as the autocorrelated variables: $\mathrm{NO}_{3}{ }^{-}, \mathrm{Ca}, \mathrm{Ba}, \mathrm{Cl}^{-}, \mathrm{Mg}, \mathrm{Sr}$, DIC and conductivity values $(r>0.75)$. In this instance, uranium was the most significant of the correlated variables. Three samples, EFK 6.3 (bank and mid-channel) and the WCK 3.9 bank sample, taken in July were associated with the increased $\mathrm{MeHg}$ concentrations in the streams. These samples had higher relative abundances of Desulfobacca and Desulfonema. The remaining samples in the analysis of the 24-sample subset had RDA scores near zero, and there was not enough evidence to draw conclusions on the relationships between the samples and geochemical parameters.

Because a large proportion of the variation in the microbial communities in the stream sediments could be attributed to the BCK 12.3 samples that contained U(VI), an additional RDA was performed excluding the BCK 12.3 samples. The RDA Axes 1 and 2 of the 20 -sample subset analysis described $24.8 \%$ of the variation of the microbial composition between the samples ( $\mathrm{p}=0.04, F=2.08)$ (Fig. 3B). Samples taken from EFK 6.3 in July 2008 were most highly correlated to $\mathrm{MeHg}$ concentrations $(\mathrm{R}=$ 0.7785). These samples had high abundances of Desulfobulbus, Desulfonema and unclassified Desulfo- bacterales. The May EFK 6.3, the May EFK 23.4 bank sample and both WCK 3.9 samples all had positive RDA 1 scores but could not be significantly correlated to any geochemical factor or group of Deltaproteobacteria. July samples from EFK 13.8 and HCK 20.6 were significantly correlated with stream water turbidity $(R=0.7047)$ and had higher abundances of Desulfuromonas. Samples from WCK 3.9 taken in May were characterized by higher abundances of unclassified Deltaproteobacteria and tended to have higher concentrations of dissolved oxygen $(\mathrm{R}=0.5128)$.

Further examination of the $\mathrm{Hg}$ and $\mathrm{MeHg}$ concentrations in the EFK stream indicated decreasing $\mathrm{Hg}$ (both sedimentary and dissolved) in the sites traveling downstream of the point source and increasing $\mathrm{MeHg}$ concentrations moving downstream (Fig. 4A). While only 3 points of data are shown, more comprehensive analyses showing the same decreasing trend of $\mathrm{Hg}(\mathrm{II})$ and increasing $\mathrm{MeHg}$ has been performed (Brooks \& Southworth 2011). While there was a positive correlation of increasing $\mathrm{MeHg}$ concentrations with the abundances of Desulfonema spp. $(\mathrm{r}=0.617$, $\mathrm{p}=0.054)$ and Desulfobulbus spp. $(\mathrm{r}=0.403, \mathrm{p}=$ 0.069) going downstream, these relationships were not statistically significant (Fig. 4B). 

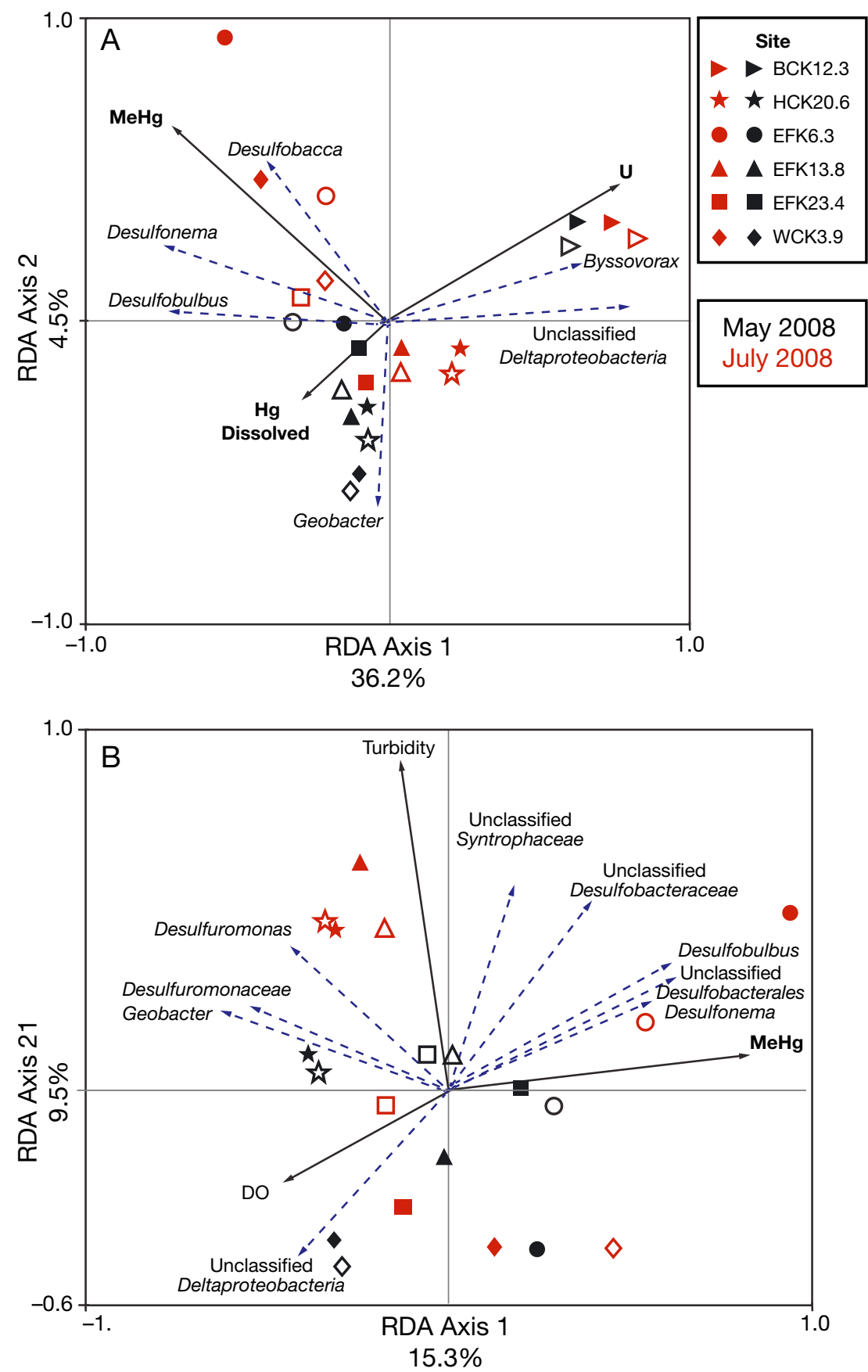

Fig. 3. Triplot of the redundancy analysis (RDA) for bacterial taxa from (A) the 24 stream sediments samples at 6 sites and (B) the 20 stream sediments samples at 5 sites (BCK samples excluded), all sites located on or near the Oak Ridge Reservation, with forward selection of predictor variables followed by Monte Carlo permutations. Solid arrows represent predictor (geochemical) variables significantly associated $(\mathrm{p}<0.05)$ with the variation in the bacterial community structure. Dashed arrows represent individual taxa ( $|r|>0.6)$ significantly associated with the variation among samples. The length of the arrow is correlated with the degree of relation between the response variables. The arrows point in the direction of the maximum change for the associated variable. Open symbols: midchannel, closed: near bank, DO: dissolved oxygen. Keys apply to both (A) and (B)

\section{Phylogenetic comparison with cultured sequences}

Several of the sequences detected in the present study grouped within the clusters of known methylators and within 0.02 changes per nucleotide position, suggesting that these bacteria may be responsible for $\mathrm{Hg}$ methylation in the sediments. These results were observed from a cluster analysis at $97 \%$ similarity level that resulted in 34 clusters. Clusters containing $\leq 10$ sequences were eliminated from further analysis, leaving 13 clusters. The phylogenetic relationship between representative sequences from each of the 13 clusters and sequences from 36 cultured Deltaproteobacteria is presented (Fig. 5). Most notable was the predominant Deltaproteobacteria cluster of 329 sequences (3-fold larger than any other found) from EFK 6.3 being closely related to Desulfobulbus propionicus strain 1pr3, an organism capable of $\mathrm{Hg}$ methylation (Benoit et al. 2001). The other known Hg methylating strain of Desulfobulbus propionicus (MUD10) did not have 16S sequences available for comparison (Rodríguez-González al. 2009). There were also 2 clusters (93 sequences total) that were closely related to Desulfomonas palmitatis from EFK 13.8 and 6.3, and 1 cluster (31 sequences) from EFK 13.8 that grouped closely with Geobacter sulfurreducens; both of those related species are known to methylate $\mathrm{Hg}$. An additional 107 sequences were found from EFK 6.3 that are most closely related to $G$. chapelli. While this organism has not been tested for methylation, 3 other members of this genus tested to date are capable of methylation (Kerin et al. 2006, Schaefer \& Morel 2009). Two clusters (152 sequences total) were closely related to Byssovorax cruenta, while another cluster (52 sequences) was more similar to members of the class Мухоcoccales. No clusters were identified that contained sequences of the known methylator Desulfovibrio desulfuricans ND132 (Jay et al. 2002). 

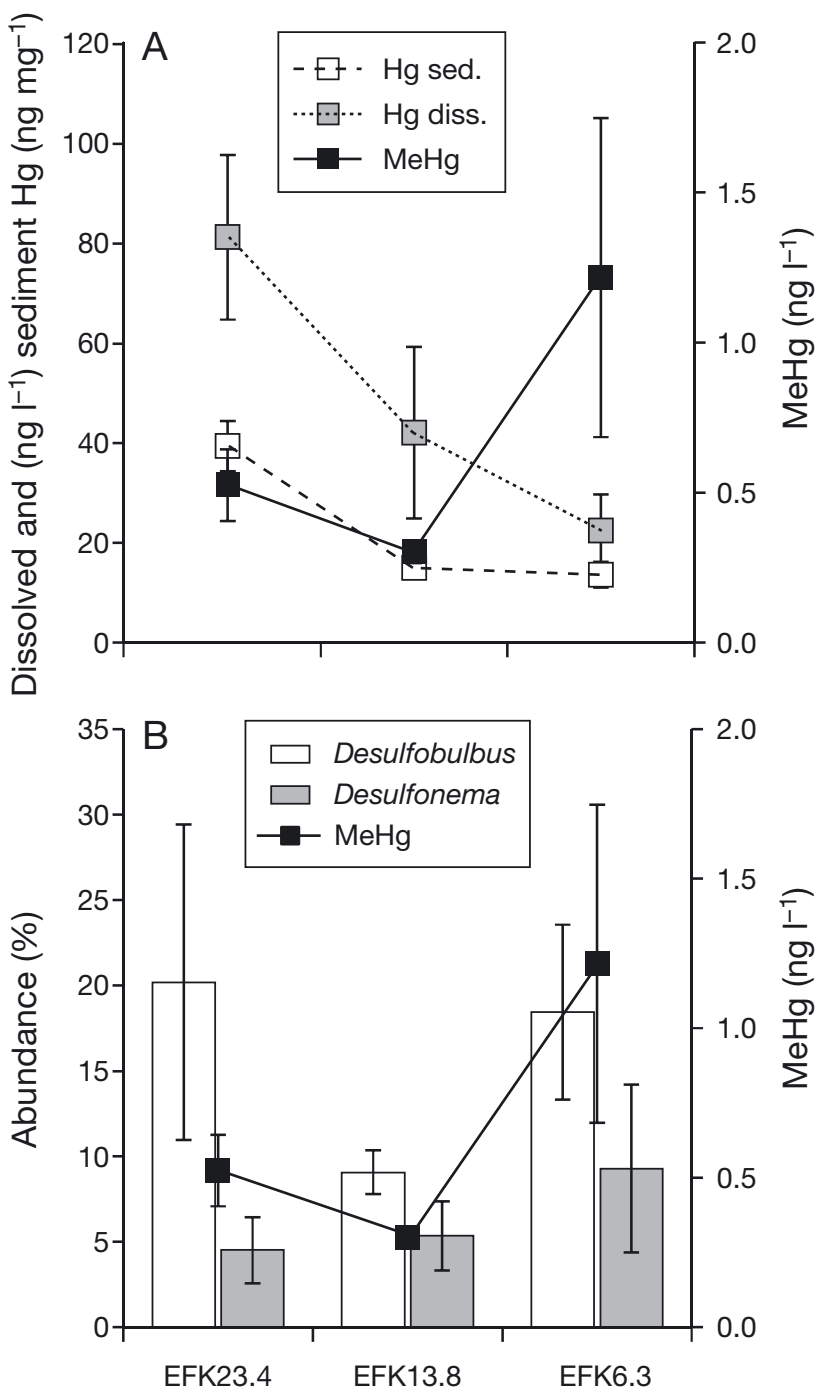

Fig. 4. (A) Concentrations of dissolved (diss.) Hg, sediment (sed.) $\mathrm{Hg}$ and $\mathrm{MeHg}$ and (B) percent abundance of Desulfobulbus spp., Desulfonema spp. and $\mathrm{MeHg}$ concentrations

in EFK sites traveling downstream of a point source

\section{DISCUSSION}

The present study revealed positive trends among the distribution of members of the Deltaproteobacteria in stream sediments with varying levels of $\mathrm{Hg}$, $\mathrm{MeHg}$ and other metal contamination, some of which have close relatives that are able to methylate mercury. While these trends revealed statistical significance, several other geochemical parameters may contribute, either in a positive or negative manner, to these observed trends. It has been noted that the trends in mercury and methyl mercury are more pronounced in the summer months (Brooks \& Southworth 2011), and the detailed analyses presented were concentrated on the warm season.
In the RDA analysis performed with samples from all 3 months (36 samples), positive relationships were observed between the $\mathrm{Hg}$ (II) concentrations (both dissolved and sedimentary) and relative abundances of Desulfobulbus spp. These correlations were observed in the sites with the highest concentrations of inorganic $\mathrm{Hg}$. When $\mathrm{MeHg}$ concentrations were added to the analysis based on 2 sampling dates (24 samples), there was a shift in the significance of the Desulfobulbus spp. toward MeHg concentrations (as well as Desulfobacca spp. and Desulfonema spp.). Desulfobulbus propionicus, the closest match to the representative sequence from the cluster analysis, has been shown to methylate $\mathrm{Hg}$ under sulfatereducing and/or fermentative conditions (King et al. 2000, Benoit et al. 2001, Kerin et al. 2006, RodríguezGonzález et al. 2009), is often found in high abundances where MeHg is present (Achá et al. 2005) and has been shown to have a positive net MeHg production (Bridou et al. 2011).

The Desulfonema spp. sequences in the present study are phylogenetically similar to isolated strains of D. ishimotonii and D. limicola. Desulfonema are filamentous sulfate-reducing bacteria that are capable of oxidizing acetate and other small aliphatic acids completely to $\mathrm{CO}_{2}$ (Widdel et al. 1983, Fukui et al. 1999) in marine and freshwater environments (Elshahed et al. 2003, Kondo \& Butani 2007, Wang et al. 2008, Teske et al. 2009). Desulfobacca is a monospecific genus represented by $D$. acetoxidans, a mesophilic sulfate-reducer that oxidizes acetate (Oude Elferink et al. 1999), was isolated from granular sludge and has been reported in metal- and sulfatecontaminated wastewater and acidic fens (Kaksonen et al. 2004, Loy et al. 2004, Shelobolina et al. 2007). Although both of these organisms are known dissimilatory sulfate-reducers, no available studies have been conducted on the ability of either to methylate $\mathrm{Hg}$.

The Deltaproteobacteria community in BCK 12.3 appeared to be distinct from the other 5 sites in the study and was predominately composed of Byssovorax and unclassified Deltaproteobacteria that significantly correlated with U(VI) concentrations in the stream water. However, several other parameters equally auto-correlated with $\mathrm{U}(\mathrm{VI})$, such as $\mathrm{NO}_{3}{ }^{-}, \mathrm{Ca}$, $\mathrm{Ba}, \mathrm{Cl}^{-}, \mathrm{Mg}, \mathrm{Sr}, \mathrm{DIC}$ and conductivity. The Byssovorax sequences identified in the present study clustered with the only known species of Byssovorax, $B$. cruenta, a cellulolytic myxobacterium (Treude et al. 2003, Reichenbach et al. 2006). Little is known about the metabolism of this bacterium in natural environments, but it has been found in high nitrate environments (Sanford et al. 2002, Noll et al. 2005), which 


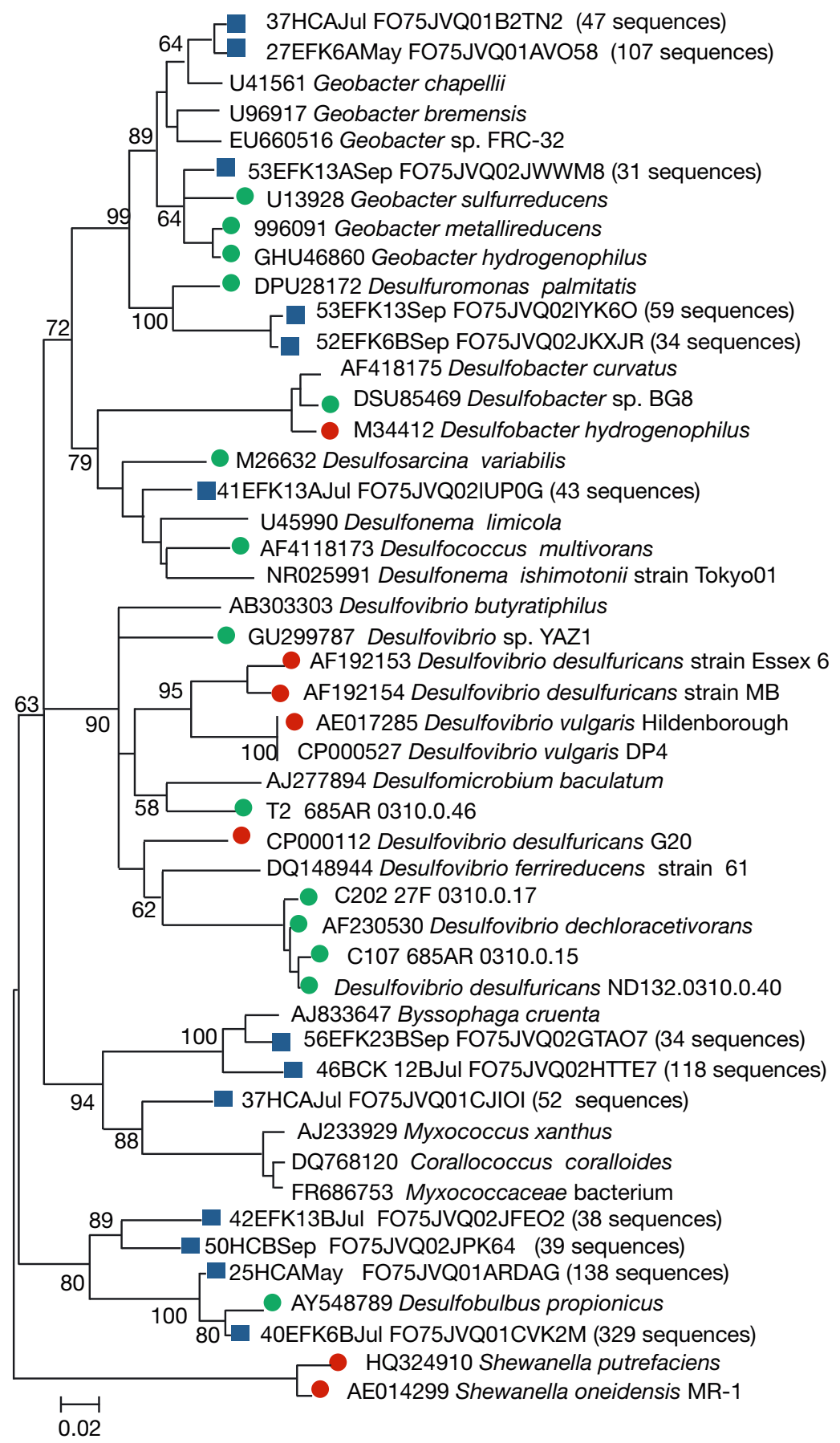

Fig. 5. Phylogenetic relationships of 13 representative environmental sequences ( $\square$ ) and 36 culturable strains of Deltaproteobacteria. (○): Hg methylators; (O): non Hg methylators. Representative sequences came from clusters that grouped with known Deltaproteobacteria by the complete-linkage clustering method in the RDP pyrosequencing pipeline. The scale bar represents 0.02 changes per nucleotide position. Phylogenetic analyses were conducted in MEGA4. T: type strain

may explain the high abundance in BCK 12.3. It is unknown if these organisms display metal tolerance or reduction, and this may warrant further study.
Higher abundances of Geobacter spp. sequences were observed in the uncontaminated (HCK 20.6) site, with the majority clustering with cultured Geobacter spp. that have not been tested for $\mathrm{Hg}$ methylation (i.e. G. chapelleii and G. bremensis). However, Geobacter sequence clusters from the contaminated sites were related to a combination of methylators and those not yet tested for methylation (i.e. G. hydrogenophilus, G. metallireducens and Geobacter sp. FRC-32). While several members of the genus produce $\mathrm{MeHg}$ (i.e. G. hydrogenophilus, G. metallireducens strain GS-15 and G. sulfurreducens) (Kerin et al. 2006), the abundance of the Geobacter spp. present in the samples were not statistically correlated to any measured geochemical or physical factors (i.e. $\mathrm{Hg}$ or $\mathrm{MeHg}$ concentrations).

It is evident from the data and historical knowledge (Brooks \& Southworth 2011) that the source of $\mathrm{Hg}$ (II) is in the upstream waters of EFK (near EFK 23.4) and that MeHg concentrations increase with distance downstream to EFK 6.3. This suggests that methylation actively occurs in these systems. Although at this time there is no direct evidence to pinpoint the exact location of methylation (e.g. surface sediments, subsurface sediments and riparian soils) and which organisms are responsible for $\mathrm{Hg}$ methylation, the presence and abundance of organisms that are closely related to known $\mathrm{Hg}$ methylating Deltaproteobacteria in the stream sediments, specifically Desulfobulbus spp., were statistically correlated to concentrations of $\mathrm{MeHg}$ in the stream water. Functional $\mathrm{Hg}$ methylation assays of isolates within and outside the Deltaproteobacteria are required to examine these correlations in more detail. Additional sampling in deeper sediments from the stream channel and the riparian zones are planned to help delineate these relationships and to determine rates of $\mathrm{Hg}$ methylation throughout the watershed. 


\section{CONCLUSIONS}

The results of the present study allowed for the identification of bacteria that may contribute to $\mathrm{Hg}$ methylation in stream sediments. Strong correlations were demonstrated between $\mathrm{Hg}$ and $\mathrm{MeHg}$ concentrations and close relatives of known $\mathrm{Hg}$ methylators, specifically Desulfobulbus propionicus. The phylogenetic relationship of the sequences detected in the current study to cultured strains of $D$. propionicus gave further support to the notion that bacteria similar to $D$. propionicus may play a role in $\mathrm{Hg}$ methylation in surface stream sediments at sites near Oak Ridge, $\mathrm{TN}_{\text {; }}$ however, further physiological studies are required to examine these relationships more closely. These findings shed light on possible site-specific methylators and form the basis for the future isolation of these sitespecific methylators.

Acknowledgements. We thank L. Fagan, M. Rodriguez, Jr., Z. Yang, and M. Kerley of ORNL for their help with sample collection and analysis. This work was supported by the U.S. Department of Energy's Office of Science Biological and Environmental Research, Subsurface Biogeochemical Research program to the Oak Ridge National Laboratory Hg Science Focus Area. Oak Ridge National Laboratory is managed by UT-Battelle for the U.S. Department of Energy under contract DE-AC05-00OR22725. Accordingly, the U.S. Government retains a nonexclusive, royalty-free license to publish or reproduce the published form of this contribution, or allow others to do so, for U.S. Government purposes.

\section{LITERATURE CITED}

Achá D, Iniguez V, Roulet M, Guimaraes JRD, Luna R, Alanoca L, Sanchez S (2005) Sulfate-reducing bacteria in floating macrophyte rhizospheres from an Amazonian floodplain lake in Bolivia and their association with Hg methylation. Appl Environ Microbiol 71: 7531-7535

- Barnett MO, Harris LA, Turner RR, Henson TJ, Melton RE, Stevenson RJ (1995) Characterization of mercury species in contaminated floodplain soils. Water Air Soil Pollut 80: 1105-1108

> Benoit JM, Gilmour CC, Mason RP (2001) Aspects of bioavailability of mercury for methylation in pure cultures of Desulfobulbus propionicus (1pr3). Appl Environ Microbiol 67:51-58

> Bloom NS, Gill GA, Cappellino S, Dobbs C and others (1999) Speciation and cycling of mercury in Lavaca Bay, Texas, sediments. Environ Sci Technol 33:7-13

Bridou R, Monperrus M, Gonzalez PR, Guyoneaud R, Amouroux D (2011) Simultaneous determination of mercury methylation and demethylation capacities of various sulfate-reducing bacteria using species-specific isotopic tracers. Environ Toxicol Chem 30:337-344

Brooks SC, Southworth GR (2011) History of mercury use and environmental contamination at the Oak Ridge Y-12 Plant. Environ Pollut 159:219-228

Clarkson TW (1998) Human toxicology of mercury. J Trace Elem Exp Med 11:303-317

Cole JR, Wang Q, Cardenas E, Fish J and others (2009) The Ribosomal Database Project: improved alignments and new tools for rRNA analysis. Nucleic Acids Res 37: D141-D145

Devereux R, Winfrey MR, Winfrey J, Stahl DA (1996) Depth profile of sulfate-reducing bacterial ribosomal RNA and mercury methylation in an estuarine sediment. FEMS Microbiol Ecol 20:23-31

Dowd SE, Sun Y, Secor PR, Rhoads DD, Wolcott BM, James GA, Wolcott RD (2008) Survey of bacterial diversity in chronic wounds using pyrosequencing, DGGE, and full ribosome shotgun sequencing. BMC Microbiol 8:43 doi: 10.1186/1471-2180-8-43

- Ekstrom EB, Morel FMM (2008) Cobalt limitation of growth and mercury methylation in sulfate-reducing bacteria. Environ Sci Technol 42:93-99

- Ekstrom EB, Morel FMM, Benoit JM (2003) Mercury methylation independent of the acetyl-coenzyme A pathway in sulfate-reducing bacteria. Appl Environ Microbiol 69: 5414-5422

- Oude Elferink SJWH, Akkermans-van Vliet WM, Bogte JJ, Stams AJM (1999) Desulfobacca acetoxidans gen. nov., sp. nov., a novel acetate-degrading sulfate reducer isolated from sulfidogenic granular sludge. Int J Syst Bacteriol 49:345-350

Elshahed MS, Senko JM, Najar FZ, Kenton SM and others (2003) Bacterial diversity and sulfur cycling in a mesophilic sulfide-rich spring. Appl Environ Microbiol 69:5609-5621

> Felsenstein J (1985) Confidence limits on phylogenies: an approach using the bootstrap. Evolution 39:783-791

Fleming EJ, Mack EE, Green PG, Nelson DC (2006) Mercury methylation from unexpected sources: molybdateinhibited freshwater sediments and an iron-reducing bacterium. Appl Environ Microbiol 72:457-464

> Fukui M, Teske A, Assmus B, Muyzer G, Widdel F (1999) Physiology, phylogenetic relationships, and ecology of filamentous sulfate-reducing bacteria (genus Desulfonema). Arch Microbiol 172:193-203

Gilmour CC, Henry EA, Mitchell R (1992) Sulfate stimulation of mercury methylation in fresh-water sediments. Environ Sci Technol 26:2281-2287

Gray JE, Hines ME, Higueras PL, Adatto I, Lasorsa BK (2004) Mercury speciation and microbial transformations in mine wastes, stream sediments, and surface waters at the Almaden Mining District, Spain. Environ Sci Technol 38:4285-4292

Han FX, Su Y, Monts DL, Waggoner CA, Plodinec MJ (2006) Binding, distribution, and plant uptake of mercury in a soil from Oak Ridge, Tennessee, USA. Sci Total Environ 368:753-768

Holloway JM, Goldhaber MB, Scow KM, Drenovsky RE (2009) Spatial and seasonal variations in mercury methylation and microbial community structure in a historic mercury mining area, Yolo County, California. Chem Geol 267:85-95

Jay JA, Murray KJ, Gilmour CC, Mason RP, Morel FMM, Roberts AL, Hemond HF (2002) Mercury methylation by Desulfovibrio desulfuricans ND132 in the presence of polysulfides. Appl Environ Microbiol 68:5741-5745 
Kaksonen AH, Plumb JJ, Franzmann PD, Puhakka JA (2004) Simple organic electron donors support diverse sulfatereducing communities in fluidized-bed reactors treating acidic metal- and sulfate-containing wastewater. FEMS Microbiol Ecol 47:279-289

Kerin EJ, Gilmour CC, Roden E, Suzuki MT, Coates JD, Mason RP (2006) Mercury methylation by dissimilatory iron-reducing bacteria. Appl Environ Microbiol 72: 7919-7921

King JK, Kostka JE, Frischer ME, Saunders FM (2000) Sulfate-reducing bacteria methylate mercury at variable rates in pure culture and in marine sediments. Appl Environ Microbiol 66:2430-2437

Kondo R, Butani J (2007) Comparison of the diversity of sulfate-reducing bacterial communities in the water column and the surface sediments of a Japanese meromictic lake. Limnology 8:131-141

Krekeler D, Sigalevich P, Teske A, Cypionka H, Cohen Y (1997) A sulfate-reducing bacterium from the oxic layer of a microbial mat from Solar Lake (Sinai), Desulfovibrio oxyclinae sp. nov. Arch Microbiol 167:369-375

Leps J, Smilauer P (2003) Multivariate analysis of ecological data using CANOCO. Cambridge University Press, Cambridge

> Loy A, Kusel K, Lehner A, Drake HL, Wagner M (2004) Microarray and functional gene analyses of sulfatereducing prokaryotes in low-sulfate, acidic fens reveal cooccurrence of recognized genera and novel lineages. Appl Environ Microbiol 70:6998-7009

> Nawrocki EP, Eddy SR (2007) Query-dependent banding (QDB) for faster RNA similarity searches. PLOS Comput Biol 3:e56

Noll M, Matthies D, Frenzel P, Derakshani M, Liesack W (2005) Succession of bacterial community structure and diversity in a paddy soil oxygen gradient. Environ Microbiol 7:382-395

> Oregaard G, Sorensen SJ (2007) High diversity of bacterial mercuric reductase genes from surface and sub-surface floodplain soil (Oak Ridge, USA). ISME J 1:453-467

> Marvin-DiPasquale MMD, Lutz MA, Brigham ME, Krabbenhoft DP, Aiken GR, Orem WH, Hall BD (2009) Mercury cycling in stream ecosystems. 2. Benthic methylmercury production and bed sediment-pore water partitioning. Environ Sci Technol 43:2726-2732

> Porat I, Vishnivetskaya TA, Mosher JJ, Brandt CC and others (2010) Characterization of archaeal community in contaminated and uncontaminated surface stream sediments. Microb Ecol 60:784-795

> Ranchou-Peyruse M, Monperrus M, Bridou R, Duran R, Amouroux D, Salvado JC, Guyoneaud R (2009) Overview of mercury methylation capacities among anaerobic bacteria including representatives of the sulphate-reducers: implications for environmental studies. Geomicrobiol J 26:1-8

Ravenschlag K, Sahm K, Knoblauch C, Jorgensen BB, Amann R (2000) Community structure, cellular rRNA content, and activity of sulfate-reducing bacteria in marine arctic sediments. Appl Environ Microbiol 66: 3592-3602

Reichenbach H, Lang E, Schumann P, Sproer C (2006) Byssovorax cruenta gen. nov., sp. nov., nom. rev., a cellulose-degrading myxobacterium: rediscovery of 'Myxococcus cruentus' Thaxter 1897. Int J Syst Evol Microbiol $56: 2357-2363$
Rodríguez-González P, Epov VN, Bridou R, Tessier E, Guyoneaud R, Monperrus M, Amouroux D (2009) Speciesspecific stable isotope fractionation of mercury during $\mathrm{Hg}$ (II) methylation by an anaerobic bacteria (Desulfobulbus propionicus) under dark conditions. Environ Sci Technol 43:9183-9188

Saitou N, Nei M (1987) The neighbor-joining method: a new method for reconstructing phylogenetic trees. Mol Biol Evol 4:406-425

Sanford RA, Cole JR, Tiedje JM (2002) Characterization and description of Anaeromyxobacter dehalogenans gen. nov., sp. nov., an aryl-halorespiring facultative anaerobic myxobacterium. Appl Environ Microbiol 68:893-900

Schaefer JK, Morel FMM (2009) High methylation rates of mercury bound to cysteine by Geobacter sulfurreducens. Nat Geosci 2:123-126

Shelobolina ES, Nevin KP, Blakeney-Hayward JD, Johnsen CV and others (2007) Geobacter pickeringii sp. nov., Geobacter argillaceus sp. nov. and Pelosinus fermentans gen. nov., sp. nov., isolated from subsurface kaolin lenses. Int J Syst Evol Microbiol 57:126-135

Sigalevich P, Cohen Y (2000) Oxygen-dependent growth of the sulfate-reducing bacterium Desulfovibrio oxyclinae in coculture with Marinobacter sp. strain MB in an aerated sulfate-depleted chemostat. Appl Environ Microbiol 66:5019-5023

Sigalevich P, Baev MV, Teske A, Cohen Y (2000a) Sulfate reduction and possible aerobic metabolism of the sulfatereducing bacterium Desulfovibrio oxyclinae in a chemostat coculture with Marinobacter sp. strain MB under exposure to increasing oxygen concentrations. Appl Environ Microbiol 66:5013-5018

Sigalevich P, Meshorer E, Helman Y, Cohen Y (2000b) Transition from anaerobic to aerobic growth conditions for the sulfate-reducing bacterium Desulfovibrio oxyclinae results in flocculation. Appl Environ Microbiol 66: 5005-5012

Tamura K, Nei M, Kumar S (2004) Prospects for inferring very large phylogenies by using the neighbor-joining method. Proc Natl Acad Sci USA 101:11030-11035

Tamura K, Dudley J, Nei M, Kumar S (2007) MEGA4: molecular evolutionary genetics analysis (MEGA) software version 4.0. Mol Biol Evol 24:1596-1599

Teske A, Jorgensen BB, Gallardo VA (2009) Filamentous bacteria inhabiting the sheaths of marine Thioploca spp. on the Chilean continental shelf. FEMS Microbiol Ecol 68:164-172

> Treude N, Rosencrantz D, Liesack W, Schnell S (2003) Strain FAc12, a dissimilatory iron-reducing member of the Anaeromyxobacter subgroup of Myxococcales. FEMS Microbiol Ecol 44:261-269

Tsui MTK, Finlay JC, Balogh SJ, Nollet YH (2010) In situ production of methylmercury within a stream channel in northern California. Environ Sci Technol 44:6998-7004

Vishnivetskaya TA, Mosher JJ, Palumbo AV, Yang ZK and others (2011) Mercury and other heavy metals influence bacterial community structure in contaminated Tennessee streams. Appl Environ Microbiol 77:302-311

> Wang S, He J (2011) Separation of fluorescence-labelled terminal restriction fragment DNA on a two-dimensional gel (T-RFs-2D) - an efficient approach for microbial consortium characterization. Environ Microbiol 13: 2565-2575

> Wang Q, Garrity GM, Tiedje JM, Cole JR (2007) Naive 
Bayesian classifier for rapid assignment of rRNA sequences into the new bacterial taxonomy. Appl Environ Microbiol 73:5261-5267

Wang MY, Liang XB, Yuan XY, Zhang W, Zeng J (2008) Analyses of the vertical and temporal distribution of sulfate-reducing bacteria in Lake Aha (China). Environ Geol 54:1-6

Widdel F, Kohring GW, Mayer F (1983) Studies on dissimila-

Editorial responsibility: Tom Battin,

Vienna, Austria tory sulfate-reducing bacteria that decompose fatty acids. Arch Microbiol 134:286-294

Youssef N, Sheik CS, Krumholz LR, Najar FZ, Roe BA, Elshahed MS (2009) Comparison of species richness estimates obtained using nearly complete fragments and simulated pyrosequencing-generated fragments in 16S rRNA gene-based environmental surveys. Appl Environ Microbiol 75:5227-5236

Submitted: December 7, 2011; Accepted: March 16, 2012 Proofs received from author(s): June 22, 2012 